\title{
Peer Tutoring Assisted Guided Inquiry Learning Model on Students' Knowledge Competency of Mathematics
}

\author{
*Putu Dian Valentina Darmayanti¹, I Wayan Wiarta ${ }^{2}$, Ida Bagus Gede Surya Abadi ${ }^{3}$
}

1,2,3Program Studi Pendidikan Guru Sekolah Dasar, Universitas Pendidikan Ganesha, Singaraja, Indonesia

\section{A R T I C L E I N F O}

Article history:

1 Mei 2020 Received in

revised form

11 Juni 2020

Accepted 10 Juli 2020

Available online 25 Agustus 2020

\section{Kata Kunci:}

Inkuiri terbimbing, tutor

sebaya, matematika.

Keywords:

Guided inquiry, peer

tutoring, mathematics

\begin{abstract}
A B S T R A K
Rendahnya kompetensi pengetahuan matematika siswa menjadi permasalahan utama penelitian ini. Hal tersebut disebabkan kurangnya model pembelajaran yang efektif dan peran siswa di kelas masih menjadi penerima materi yang mengakibatkan siswa menjadi pasif. Penelitian ini bertujuan untuk mengetahui pengaruh yang signifikan model pembelajaran inkuiri terbimbing berbantuan tutor sebaya terhadap kompetensi pengetahuan matematika kelas V SD. Jenis penelitian yakni eksperimen semu dengan rancangan non-equivalent control group design. Banyak populasi yakni 329 siswa kelas V SD sedangkan sampel yang dipergunakan sebanyak 66 siswa dengan mempergunakan teknik cluster random sampling. Pengumpulan data mempergunakan metode tes dengan instrumen tes berbentuk pilihan ganda biasa. Data yang dianalisis adalah gain skor ternormalisasi dari hasil pretest dan posttest mempergunakan uji $\mathrm{t}$ polled varians.
\end{abstract}

Didapatkan thitung $=12,298$ untuk $\mathrm{dk}=64$ pada $\alpha=0,05$ sehingga didapatkan tabel $=1,998$. Oleh sebab thitung $>$ tabel artinya terjadi penolakan $\mathrm{H}_{0}$ dan penerimaan $\mathrm{H}_{\mathrm{a}}$. Dapat disimpulkan terdapat pengaruh yang signifikan model pembelajaran inkuiri terbimbing berbantuan tutor sebaya terhadap kompetensi pengetahuan matematika kelas V SD. Hasil penelitian ini dapat digunakan menjadi bahan bacaan mendalami objek penelitian yang sejenis.

\section{A B S T R A C T}

The low competency of students' mathematics knowledge was the main problem in this present study. It was due to the lack of effective learning models and the students in the class were still receivers, it made the students became passive. This study aimed to determine the significant influence of peer tutorings assisted guided inquiry learning models on students' knowledge competencys in mathematics learning for the fifth grade Elementary School. The type of the research was quasiexperimental with a non-equivalent control group design. The population was 329 the fifth-grade students of Elementary School, while the sample was 66 students by using cluster random sampling techniques. The data collection applied multiple-choice test instruments. The analyzed data were normalized score gain from the results of the pretest and post-test using the t polled variance test. The results of $t_{\text {count }}=12,298$ for $\mathrm{dk}=64$ at $\alpha=0.05$ so that the obtained table $=1.998$. Because $t_{\text {count }}>$ table, $\mathrm{H}_{0}$ was rejected and $\mathrm{H}_{\mathrm{a}}$ was accepted. The average score of the experimental group normalized score was 0.753 more than the average control group was 0.559 . It can be concluded that there is a significant influence of peer tutorings assisted guided inquiry learning models on the mathematics competency of the fifth grade Elementary School. The results of this study can be used as reading material to explore similar research objects.

Copyright (C) Universitas Pendidikan Ganesha. All rights reserved

Corresponding author

E-mail addresses: putudianvalentina@gmail.com (Dian)1 ${ }^{1}$, wayanwiarta11@gmail.com (Wiarta)2,

idabagusgedesurya.abadi@undiksha.ac.id (Surya) ${ }^{3}$ 


\section{Introduction}

Mathematics is a very important subject where students are assisted in solving daily problems and mathematics learning is given from elementary to college level (A. Badawi, Rochmad, 2016; Muhalizah, 2018). However, mathematics has a considerable amount of study time, in fact, mathematics is still considered a difficult subject. As a result, the competency of mathematics knowledge is still low. The low competency of students' mathematics knowledge is proved by the results of the annual PISA study organized by the Organization for sEconomic Cooperation and Development (OECD). In 2015, Indonesia ranked 63 out of 70 countries with a score of 386 from the international average score of 490 (OECD, 2018). Whereas in the 2018 PISA results, Indonesia decreases to 73 rank from 79 countries with a score of 379 while the international average was 489 (OECD, 2018). Indonesia is always in the top ten positions from the bottom for mathematics content. A similar study was also conducted by the Ministry of Education and Culture through the Indonesia National Assessment Program/Indonesian Student Competency Assessment (AKSI) in 2016 explained the low mastery of Indonesian students' mathematics subjects. Around $77.13 \%$ of elementary school students throughout Indonesia have very low math competency, $20.58 \%$ is sufficient and only $2.29 \%$ are in good category (Ministry of Education and Culture, 2016).

This problem also occurred during conducting observations in the Lieutenant Colonel Wisnu Group, the results of the Mid-Semester Assessment (PTS) were obtained which showed that the students' competency of mathematics knowledge was not satisfied, it can be seen from the results of the midsemester assessment where there are still students got under the determined minimum completeness criteria (KKM). The results of PTS mathematics of the fifth-grade elementary school Cluster Letkol Wisnu showed that there were $61.09 \%$ of students who had not completed out of 329 students. Based on the results of conducted observation and interviews, the low mathematics competency of student's knowledge is caused by several things. First, the teacher takes more roles in mathematics learning, in the classroom the role of the teacher is still the provider of the material and students are the recipients of the material. It causes students to be passive or less active, students accept whatever is transferred by the teacher, and students have difficulty when they are given differ ent questions from the previous practice questions. It indicates that students only memorize the procedure and the students' understanding ability can be said low so the students' completeness is still under the KKM. Second, students are accustomed to learning that begins with material exposure and sample questions, then students are given similar questions that must be solved so that mathematics is only presented as a product, the teacher presents the material directly without involving students which make students are unable to find the concept of the material. Third, the use of learning models has not been optimal so that students' interest in learning mathematics is low. If the problem is not covered soon, it will greatly affect the produced outcome where students will find it difficult to solve problems in their daily life.

To overcome these problems, it requires an appropriate learning model to optimize learning activities by maximizing student involvement in gaining knowledge. One of them is guided inquiry which is part of the inquiry learning model. Guided inquiry learning is a learning activity that involves students actively to seek and investigate knowledge critically and logically with teacher guidance (Dewi, 2016; Pratiwi et al., 2018; Wati et al., 2018). Inquiry learning focuses on student activity in search and discovery which means that students are placed as the subject of learning in inquiry learning so that students do not only accept material from the teacher but act actively in discovering by themselves the content of the material (Iswatun et al., 2017; Jundu et al., 2020; Krismayeni, 2016; Sanjaya, 2010). Thus, the implementation of guided inquiry allows students to participate actively in the activities of observing, measuring, and collecting data to draw a conclusion. It means that knowledge is not only provided by the teacher but knowledge must be built or discovered by students, by finding their own students' abilities, it will be stored longer (Fiteriani \& Baharudin, 2017; Suwarti, 2019). Therefore, it can be said that the guided inquiry model is one of the discovery learning models with the guidance of the teacher.

The teacher has the role to guide students to construct their knowledge. This is due to the ability of elementary school students that cannot be fully released in learning activities. In line with the opinion of (Antara, 2017; Fahmia, 2019), the guided inquiry becomes an appropriate learning model in elementary school because the students still really need guidance from their teachers. In this learning model, the guidance refers to assistance such as important facilities and infrastructure and the attitude of the teacher as a guide. In guided inquiry learning, students are given problems by the teacher and students must try to find their own answers to these problems, and solve problems, as well as, students cannot be separated from teacher guidance (Anam, 2017; Putra, 2017; Lestari, 2017). The teacher is in charge of giving 
inducement questions to students so that they want to do something. In line with the opinion of (Muliani, 2019; Widani, 2019) which states that the guided inquiry learning model emphasizes discovery activities in the learning process to find a concept with teachers' guidance. Guided Inquiry models has advantages.

The advantage of the guided inquiry learning model is that during teaching and learning activities students are guided gradually to find the material that they are learning through conjectures, conduct investigations, collect data, and communicate to get the right conclusions, (Azizah, 2016; Kartika, 2017; Saraswati, 2013; Sefalianti, 2014). Thus, it can be said that guided inquiry model makes students learn more actively and they are still guided by the teacher.

Apart from the use of learning models, another factor that supports the success of learning is the learning method. At the age of 11, students are able to explain what they see, hear, and get from others so that students are able to provide opinions or explanations to teachers, friends, or peer groups. Therefore, one method that is able to increase student participation is peer tutoring method. The peer tutoring method gives opportunities for students to teach or share their knowledge with friends who are in the same class. Through the peer tutoring method, students can converse and interact with friends openly and still being guided by the teacher so that it can spur students to understand the lesson (Ulfa, 2014). Tutors come from students whose comprehension skills are faster and able to provide material explanations to other friends (Padmayani, 2017). The implementation of peer tutoring method is done by utilizing the students' ability who are faster learners, if someone does not understand, it will be taught by the student so that learning completeness will be fulfilled (Mastrianto, 2017). Therefore, peer tutorings are students or children who are at the same age

Peer tutorings keep students active because they are not ashamed to ask questions that they don't understand and express opinions to their friends. Peer tutoring assisted learning is usually able to give better results because the language between friends is easier to be understood. (Musdiani, 2017; Tetiwar, 2018). states that students perceive problems differently from adults and they use informal language. In addition, peer tutoring can decrease awkward feeling for students who are embarrassed to ask questions so students will not hesitate to tell their friends if they have problems.

The benefit of implementing peer tutoring method for tutors is that they will feel proud of their role and are able to learn through experience of being a tutor. Tutors can reinforce their knowledge after teaching their peers. Friends who are taught by the tutor will also have a better understanding of the material being taught. In addition, according to. (Anggorowati, 2011), it can make students happier in learning and learning activities more fun because students ask questions that they don't understand and open up more with their friends. According to (Sarini, 2018; Setiana, 2019) through peer tutoring, students and tutors will be closer to each other, can increase the sense of responsibility, and students' selfconfidence. With an increased desire to learn, learning success will be achieved.

Theoretically, the guided inquiry learning model and peer tutoring methods have a positive impact on the success of learning. There are several relevant research results that reinforce that the guided inquiry model and peer tutoring methods have a positive impact on student learning success, including a study conducted by (Saraswati, 2013) which showed that the guided inquiry model affects mathematics learning outcomes. The difference is in the place and time of implementation and the grade level under study. This study examined the fifth grade while the relevant research examined the third grade. This study was also assisted by peer tutorings, while relevant research was not assisted by peer tutorings, a study conducted by (Antara, 2017) showed that mind maps assisted guided inquiry learning model had an effect on science learning outcomes. The difference was that the subjects of the present study were mathematics, while in the relevant study was science. This research was also assisted by peer tutorings while relevant research was assisted by mind maps. In addition, the difference is also in the place and time of implementation, a study conducted by (Krismayeni, 2016) showed that the guided inquiry model can increase the activeness and learning outcomes of the fifth grade students. The difference is that this present study was assisted by peer tutorings while the relevant study was not assisted by peer tutorings. The difference was also in the place and time of implementation, a study by (Padmayani, 2017) showed that the peer tutorings assisted problem-based learning model affects mathematics learning outcomes. The difference is that this study applied a guided inquiry learning model while relevant research applied problem-based learning. The difference is also in the place and time of implementation, a study conducted by (Setiana, 2019) showed that the peer tutoring method affects students' interest and learning achievement, and a study conducted by (Mastrianto, 2017) showed that the peer tutoring model is effective for increasing students' interest in learning.

Therefore, this study aimed to examine the significant influence of peer tutoring assisted inquiry learning models on the mathematics knowledge competency of the fifth-grade elementary school Cluster Letkol Wisnu in the academic year 2019/2020. The difference between the present study and previous study was the subject matter, the place, and time of the study. 


\section{Method}

The design of the study was quantitative research following a quasi-experimental design using a non-equivalent control group design. In this design, there are two sample groups, namely the experimental and control groups. In determining the sample group, the subject or research participants were not selected randomly so that those who acted as experimental and control groups had been previously formed without any random individuals (Setyosari, 2015). In this design, one group as an experimental group was taught a peer tutoring assisted inquiry learning model and one group as a control group was not taught using a peer tutoring assisted inquiry learning model.

In this study, the population was all the fifth grade Elementary School Cluster Letkol Wisnu in the academic year 2019/2020 of 329 students. From the entire population, two classes were selected to be the research sample using cluster random sampling technique. The randomization of the sample was conducted only to randomize the classes, not individuals. It was intended that students did not know that they were participating in an experiment so that this research properly described the effect of the given treatment. The drawing was used in random sampling technique. After drawing, two classes were obtained as the research sample, namely the grade VA of Public Elementary School (SD Negeri) Number 10 Peguyangan and grade V of Public Elementary School (SD Negeri) Number 3 Peguyangan. Then, the sample equivalence test was conducted by giving a pretest to the two selected classes by lottery. The scores from the pretest results were tested for equivalence using the $t$-test. Before the sample equalization was carried out with the t-test, the prerequisite test was conducted first, namely the normality test of the data distribution and the homogeneity of the variance. After the pretest data was stated to be normally distributed and homogeneous, then the equivalence test was conducted using the $t$ polled variance test. After it was known that they were equal, a drawing was done to determine the experimental and control groups. The results of the drawing for class V SD Negeri 3 Peguyangan were 35 students as the experimental group and class VA SD Negeri 10 Peguyangan were 31 students as the control group.

The needed data was the competency of mathematics knowledge. The method used for data collection was the test method due to the collected data was quantitative. The instrument that was used to collect data on the mathematics competency of student knowledge was a test in the form of an objective test in the form of regular multiple-choice of 40 test items. Each test item was given a score of 1 if the answer was correct and a score of 0 if the answer was wrong. Then, the score of each test item was totaled and the results were used as a variable score for mastery of mathematics knowledge competency. From 40 questions, C1-C4 were the indicators of mathematics knowledge competency. The preparation of tests based on basic competency (KD) and indicators in line with the subject matter. Basic competencies (KD) and more detailed indicators were shown in table 01.

Table 01. The Basic Competency (KD) and Indicators

\begin{tabular}{|c|c|}
\hline $\begin{array}{c}\text { Basic } \\
\text { Competency (KD) }\end{array}$ & Indicators \\
\hline $\begin{array}{l}\text { Describing and } \\
\text { determining the } \\
\text { volume of a space } \\
\text { using volume units } \\
\text { (such as a unit } \\
\text { cube) and the } \\
\text { cubed relationship } \\
\text { with the cube root. }\end{array}$ & $\begin{array}{l}\text { 1. Identifying the objects around like cubes and blocks. } \\
\text { 2. Describing a cube and a block. } \\
\text { 3. Calculating the volume of a cube and block using the unit cubes and } \\
\text { blocks. } \\
\text { 4. Identifying the volume formulas for cubes and cubes. } \\
\text { 5. Determining the volume of the cube and block. } \\
\text { 6. Calculating the length of the side from the volume of the cube. } \\
\text { 7. Determining the volume of blocks whose base area and height are } \\
\text { 8. Determining the length, width, and height of the blocks. } \\
\text { 9. Solving the problems related to the volume of cubes and blocks. }\end{array}$ \\
\hline
\end{tabular}

Before conducting the test, the instrument testing was conducted first with the item validity test, the difference power test, the difficulty level test, and the reliability test. Instrument testing was carried out with the aim at obtaining instruments that were suitable to be used as research instruments. 31 test items met the requirements. After the data had been collected, data analysis was then done. Normalized score gain was the data analysis method. The processed or analyzed data in both groups was the normalized score gain from the pre-test and post-test results. After obtaining the normalized score gain 
data, then the average, variance, and standard deviation of the normalized score gain data were normalized. Then, the competency of mathematics knowledge was determined by converting the average using PAN 5 scales.

Inferential statistical analysis was the data analysis technique which was a way of processing data done through the application of inferential statistical formulas in hypothesis testing to draw conclusions. Data were analyzed using polled variance t-test. However, the prerequisite analysis test was conducted first with the normality test using the Kolmogorov-Smirnov formula and the homogeneity test applied the F-test before testing the hypothesis.

\section{Result and Discussion}

The analyzed competency data of mathematics knowledge were the normalized score gain data from the pre-test and post-test results. The recapitulation of the normalized score gain data of the experimental and control groups in detail was presented in table 02.

Table 02. The Description Recapitulation Data of Gain Normalized Score of Mathematics Knowledge Competency in Experimental and Control Group

\begin{tabular}{ccc}
\hline Statistic & Experimental Group & Control Group \\
\hline Average & 0,753 & 0,559 \\
Standard Deviation & 0,069 & 0,059 \\
Variance & 0,0047 & 0,0034 \\
Maximum Gain Normalized Score & 0,889 & 0,667 \\
Minimum Gain Normalized Score & 0,667 & 0,480 \\
\hline
\end{tabular}

The recapitulation results of normalized score gain data on mathematics knowledge competency stated that the experimental group obtained an average value of 0.753 more than the average value of the control group of 0.559 . Then, the competency of mathematics knowledge of the experimental and control groups was determined by converting the average using 5 scales of PAN. The average normalized score gain of the experimental group was $\bar{X}=0.753$ lied in the score range $0.7185 \rightarrow<0.7875$ which was considered sufficient. Thus, it is known that the competency of the experimental group on mathematics knowledge using five scales of PAN was in the sufficient predicate. The normalized average score gain of the control group was $\bar{X}=0.559$ lied in the score range $0.5295 \rightarrow<0.5885$ which was categorized as sufficient. Thus, it is known that the mathematics knowledge competency in control group using five scales of PAN was in the sufficient predicate.

Before testing the hypothesis, the prerequisite analysis test was conducted by testing the normality of the data distribution and the homogeneity of the variance. Based on the results of the experimental group normality test, the maximum value of $|\mathrm{Ft}-\mathrm{Fs}|=0.123$. At $\alpha=0.05$ and $n=35$, so the KolmogorovSmirnov table value was 0.230 . Hence, the maximum value of $|\mathrm{Ft}-\mathrm{Fs}|<$ Kolmogorov-Smirnov table value means that the distribution of data from the normalized score gain data of the mathematics competency of the experimental group is normally distributed. Likewise, according to the normality test results of the control group the maximum value of $|\mathrm{Ft}-\mathrm{Fs}|$ was obtained $=0.142$. At $\alpha=0.05$ and $\mathrm{n}=31$, the Kolmogorov-Smirnov table value is 0.244 . Hence the maximum value of $|\mathrm{Ft}-\mathrm{Fs}|<$ Kolmogorov-Smirnov table value means that the distribution of data from the normalized score gain data of the control group's mathematics knowledge competency is normally distributed.

After the data was normally distributed, the variance homogeneity test was conducted. The obtained value of $F_{\text {count }}=1.382$. With $\alpha=0.05$ and the $\mathrm{dk}$ in the numerator was $35-1=34$ and the $\mathrm{dk}$ in the denominator was $31-1=30$, so the obtained value of $F_{\text {table }}=1.818$. Therefore, $F_{\text {count }}<F_{\text {table }}$ means that the gain data score is normalized competency on mathematics knowledge of the experimental group and the control group belonged as a homogeneous variance.

The obtained data were distributed and homogeneous. Then, the next hypothesis testing was conducted using the $\mathrm{t}$-polled variance test. Based on the results of the $\mathrm{t}$-test analysis, it was found that $\mathrm{t}=$ 12.298. Then, it was compared with $t_{\text {table }}$ at $\alpha=0.05$ and $\mathrm{dk}=35+31-2=64$ in order to obtain table $=$ 1.998. Therefore, $t_{\text {count }}>t_{\text {table }}$ means that $H_{0}$ was rejected and $H_{a}$ was accepted. It means that there is a significant difference in the mathematics knowledge competency of a group that was taught using peer tutorings assisted the guided inquiry learning model and groups that were not taught using the peer tutorings assisted guided inquiry learning model in the fifth-grade elementary school in Cluster Letkol Wisnu in the academic year 2019/2020. 
Based on the data description, it was found that the mathematics knowledge competency of the experimental and control groups was in the sufficient predicate. The same predicate was caused by several factors, namely the use of the same curriculum (2013 curriculum), the same educational background of teacher, namely a bachelor's degree in primary school, and the same learning resources (ESPS (Erlangga Straight Point Series) book and students' worksheet LKS)

The results of the t-test analysis showed that the value of $t_{\text {count }}=12.298$. Then, it was compared with table at $\alpha=0.05$ and $\mathrm{dk}=35+31-2=64$ to obtain $\mathrm{t}_{\text {table }}=1.998$. Therefore $\mathrm{t}_{\text {count }}>\mathrm{t}_{\text {table }}$ means that $\mathrm{H}_{0}$ was rejected and $\mathrm{H}_{\mathrm{a}}$ was accepted. It means that there is a significant difference on the mathematics knowledge competency of group that was taught using the peer tutorings assisted guided inquiry learning model and group that was not taught using peer tutorings assisted guided inquiry learning model in the fifth-grade elementary school in Cluster Letkol Wisnu in the academic year 2019/2020. In addition, when it was compared to the average gain normalized score of mathematics knowledge competency of the experimental group $\bar{X}=0.753$, that was higher than the average of the control group $\bar{X}=0.559$. It shows that peer tutorings assisted guided inquiry learning model affects the competency of mathematics knowledge in the fifth-grade elementary school in Cluster Letkol Wisnu in the academic year 2019/2020.

The difference in the mathematics knowledge competency was due to the given treatment to the experimental group running optimally. Several things show that peer tutoring assisted inquiry learning model affects students' mathematics competency.

First, it can be seen from the syntax of guided inquiry model syntax. At the stage of presenting questions or problems, it is presented in the form of LKPD (Student Worksheet) which will direct students to find the material being studied themselves. As the result, knowledge can be found by students themselves, students are not only given knowledge through direct material explanations. However, knowledge is built itself up in students' minds. Students are given problem that they must solve it with planned procedures so that the material can be found by students and it cannot be separated from the teacher's guidance. If students try and can find it for themselves, then students will be able to remember the learned material longer. In line with a study conducted by (Gunur, 2019) which suggests that the guided inquiry model makes students understand better and remembers longer because the answers of problems are found by students themselves. Then, at the stage of making a hypothesis, students are allowed to exchange opinions in making temporary answers and teacher guides them. At the stage of designing the experiment, students are given time to determine the appropriate stages to test the temporary answers that have been made with teacher guidance. At the stage of conducting experiments to obtain information, students are given guidance to find information by experimenting. At the stage of collecting and analyzing data, each group was given time to describe the obtained results. Finally, at the stage of making conclusions, students draw conclusions with teacher guidance. It makes students active and students' self-confidence grows because self-confidence arises when students perform or they are directly involved in certain activities using their thoughts to achieve the expected results. In line with a study conducted by (Azizah, 2016; Kartika, 2017; Saraswati, 2013; Sefalianti, 2014) which suggests that due to the implementation of due guided inquiry model, students are actively involved in making assumptions, conducting investigations, collecting data, and communicating any obtained evidence to obtain the right conclusion. Providing opportunities for students to express their ideas and thought patterns in solving problems expressed by the teacher make students confident and proud because students are appreciated from their existence during the learning process. In addition, the guided inquiry model also has the advantage that the active student participation during teaching and learning activities can encourage students to gain a better understanding of mathematics concepts so that students feel interested in mathematics (Sefalianti, 2014).

Second, the use of peer tutoring methods. The presence of peer tutorings who help to solve the given problems makes students to be active, they don't feel embarrassed to ask questions that are not understood and express opinions to their friends. Learning with peers makes awkward situation disappear. The use of language in discussion and teaching between friends is easier to be understood, and there is no reluctance, insecured, or embarrassed feeling so when the students get problem, they don't hesitate to ask their friends. In line with (Setiana's research, 2019) which suggests that the existence of peer tutoring methods can increase their desire to learn so the material can be understood because the use of language in peer tutorings is more familiar and students perceive problems differently from adults. Learning success can be achieved with a high desire to learn. A study conducted by (Sarini, 2018) also suggests that through peer tutoring learning students and tutors become closer each other and it can increase students' sense of responsibility and confidence. The existence of familiarity and comfort situation between students, it can foster motivation and student activity in learning.

Third, the implementation of peer tutoring assisted guided inquiry model makes the cooperation atmosphere develop well. In guided inquiry model, students learn to find and organize their own 
knowledge guided by teachers in groups. In groups, there is complementary knowledge between students who are slow in understanding will be assisted by students who are more aware of the material being studied. It is in line with the advantages of the guided inquiry learning model, namely during teaching and learning activities, students are guided gradually so that they are able to find the material in learning (Saraswati, 2013). In addition (Azizah, 2016) states that this model makes students active to be involved in making assumptions, conducting investigations, collecting data, and communicating any obtained evidence to get the right conclusions. Providing opportunities for students to express their ideas and thought patterns in solving problems makes student feel confident and proud because students feel appreciated by their existence during the learning process. In addition, (Kartika, 2017) states that this model makes an active class because students become subjects who are able to develop their ability to think, namely forming a concept based on the obtained data through investigation. In addition, (Sefalianti, 2014) states the presence of active student participation during teaching and learning activities can encourage students to gain a better understanding of mathematics concepts so students will be more interested in mathematics. Meanwhile, in peer tutorings, the friends who taught by the tutor will also have a better understanding of the material being taught. In addition, (Anggorowati, 2011) states that it can make students happier learning and learning activities more fun because students ask questions they don't understand and open up more with their friends. (Sarini, 2018) states that the existence of peer tutoring learning, makes students closer each other, and can increase students' responsibility and confidence. The existence of familiarity and comfort between students will foster students' motivation and activity in learning. In line with a study conducted by (Setiana, 2019), students are able to increase their desire to learn, so the learning material can be understood because language is easy to be understood and students view problems differently from adults. Learning success will be achieved with higher desire. The collaboration between guided inquiry model and peer tutoring, it will develop an attitude of responsibility, cooperation, self-confidence, and tolerance.

Fourth, the implementation of peer tutoring assisted guided inquiry model can increase students' self-confidence. It cannot be separated from the implementation of developed learning model which will foster self-confidence because students are allowed to find their solutions, if students are successful in finding it, it will foster self-confidence. The successful sharing with tutor will foster students' trust and pride. The peer tutoring method is learning that has the principle to activate students in learning (Y. L. S. Hayati, 2018). Peer tutoring refers to peer learning or learning assistance between students (Irsan, 2018). According to (Martini, 2018), the peer tutoring method is teaching by providing opportunities for students to teach or share their knowledge with friends who are in the same class as them. Through the peer tutoring method, students can chat and interact with their friends openly and still be guided by the teacher so that it can spur students to understand the lesson (Ulfa, 2014). The benefit of implementing the peer tutoring method for tutors is that they will feel proud of their role and can learn through experience of being a tutor. According to (Sarini, 2018), through peer tutoring learning, students and tutors will be closer and increase students' responsibility and self-confidence. The existence of familiarity and comfort between students will foster motivation and student activity in learning. In line with (Setiana, 2019), students are able to increase their desire to learn due to the implementation of peer tutoring method so the material can be understood because the use peer tutoring language is more familiar and students view problems differently from adults.

Fifth, meanwhile, the control group was only fixated on material explanations from the teacher so that the main subject was the teacher. Learning seems monotonous from the provision of material, sample questions, and questions and answers. Only a few students were enthusiastic when learning activities took place. Students were not free to express their ideas and the ability to think was not raised. This kind of learning will make students feel bored as stated by (Sobron et al., 2019) which conventional models will have an impact on students' motivation.

The results of this study are also supported by several relevant studies, namely a study conducted by (Saraswati, 2013) which shows that the guided inquiry model affects mathematics learning outcomes; a study conducted by (Antara, 2017) shows that mind map assisted guided inquiry learning model affects science learning outcomes; a study conducted by (Krismayeni, 2016) shows that guided inquiry model can increase the activeness and mathematics learning outcomes of the fifth grade students; a study conducted by (Padmayani, 2017) shows that the peer tutoring assisted problem-based learning model affects mathematics learning outcomes; a study conducted by (Setiana, 2019) shows that the peer tutoring method affects students' interest and learning achievement; and a study conducted by (Mastrianto, 2017) shows that the peer tutoring model is effective for increasing students' interest in learning.

Based on the explanation of the results and discussion, it can be said that the peer tutorings assisted guided inquiry learning model affects the competency of mathematics knowledge in the fifthgrade elementary school Cluster Letkol Wisnu in the academic year 2019/2020. The obtained implication 
is to build excellent prospects, especially in the field of education. It is because it can improve the competency of students' knowledge which is proven from the results of research analysis. The peer tutoring assisted inquiry model can be used by the teacher as an option for learning activities because students are positioned to be learning subjects. The students are encouraged to participate actively in the learning process so that knowledge can be found by students themselves, students are not only provided with knowledge through material explanations directly. In addition, with peer tutoring assistance, it causes less active students to become active because they will not be ashamed to ask questions that are not understood and express opinions to their friends. The use of these models and methods has the potential to change the view of society, which generally knows that teacher-centered learning takes place with lecturing, now it is turning into innovative learning by applying peer tutorings assisted the guided inquiry model. The implementation of these models and methods can assist the government to obtain qualified generations and meaningful learning in line with the 2013 curriculum.

\section{Conclusions}

It can be concluded that there is a significant effect of peer tutoring assisted inquiry learning model on the mathematics knowledge competency of the fifth-grade elementary school in Cluster Letkol Wisnu in the academic year 2019/2020, in other words, the guided inquiry learning model can improve students' mathematics knowledge competency.

\section{References}

A. Badawi , Rochmad, A. A. (2016). Analisis Kemampuan Berpikir Aljabar Dalammatematika Pada Siswa Smp Kelas Viii. Unnes Journal of Mathematics Education, 3(5), 76-83. https://journal.unnes.ac.id/sju/index.php/ujme/article/view/13100.

Anam, K. (2017). Pembelajaran Berbasis Inkuiri Metode dan Aplikasi. Pustaka Pelajar.

Anggorowati, N. P. (2011). Penerapan Model Pembelajaran Tutor Sebaya pada Mata Pelajaran Sosiologi. Komunitas: International Journal of Indonesian Society and Culture, 3(1). https://doi.org/10.15294/komunitas.v3i1.2303.

Antara, I. G. W. (2017). Pengaruh Model Pembelajaran Inkuiri Terbimbing terhadap Hasil Belajar IPA Siswa Kelas V SD. Jurnal Mimbar PGSD Undiksha, 5(2). http://dx.doi.org/10.23887/jjpgsd.v5i2.10813.

Azizah, H. N. (2016). Pengaruh Model Pembelajaran Inkuiri Terbimbing terhadap Kemampuan Berpikir Kritis Siswa pada Materi Energi Bunyi. Jurnal Pena Ilmiah, 1(1). https://doi.org/10.23819/pi.v1i1.2931.

Dewi, N. L. G. K. K. (2016). Pengaruh Model Pembelajaran Inkuiri Terbimbing terhadap Pemahaman Konsep IPA dengan Mengontrol Minat Belajar pada Siswa Kelas V SD. Jurnal Pendidikan Dan Pengajaran Universitas Pendidikan

Ganesha, $49(1)$. http://dx.doi.org/10.23887/jppundiksha.v49i1.9008.

Fahmia, H. (2019). Pengaruh Model Guided Inquiry terhadap Hasil Belajar Siswa pada Pembelajaran Matematika Siswa SD Kota Bengkulu. JURIDIKDAS: Jurnal Riset Pendidikan Dasar, 2(3). https://doi.org/10.33369/juridikdas.2.3.237\%20-\%20244.

Fiteriani, I., \& Baharudin. (2017). Analisis perbedaan hasil belajar kognitif menggunakan metode pembelajaran kooperatif yang berkombinasi pada materi ipa di min Bandar Lampung. Jurnal $\begin{array}{llll}\text { Pendidikan Dan Pembelajaran } & \text { 1-30. }\end{array}$ http://ejournal.radenintan.ac.id/index.php/terampil/article/viewFile/2224/1669

Gunur, B. (2019). Pemahaman Konsep Matematis Siswa Melalui Penerapan Model Pembelajaran Inkuiri Terbimbing. Edumatica: Jurnal Pendidikan Matematika, 9(2). https://core.ac.uk/download/pdf/270213146.pdf.

Hayati, N. (2013). Perbandingan Strategi Pembelajaran Mind Map Dan Concept Map Terhadap Prestasi Belajar Siswa Kelas Vii Smp Negeri 2 Sawit Boyolali Tahun Ajaran 2012/2013. http://eprints.ums.ac.id/24824/.

Hayati, Y. L. S. (2018). Pengaruh Model Pembelajaran Tutor Sebaya terhadap Kemampuan Komunikasi Matematis Siswa Sekolah Dasar. Jurnal Pendidikan: Teori, Penelitian, Dan Pengembangan, 3(8). 
http://dx.doi.org/10.17977/jptpp.v3i8.11463.

Irsan. (2018). Peningkatan Kualitas Pembelajaran Matematika melalui Penerapan Metode Tutor Sebaya pada Murid Kelas IV SDN Topa Baubau. JKPD (Jurnal Kajian Pendidikan Dasar), 3(2). https://doi.org/10.26618/jkpd.v3i2.1421.

Iswatun, I., Mosik, M., \& Subali, B. (2017). Penerapan model pembelajaran inkuiri terbimbing untuk meningkatkan KPS dan hasil belajar siswa SMP kelas VIII. Jurnal Inovasi Pendidikan IPA, 3(2), 150. https://doi.org/10.21831/jipi.v3i2.14871

Jundu, R., Tuwa, P. H., \& Seliman, R. (2020). Hasil Belajar IPA Siswa SD di Daerah Tertinggal dengan Penerapan Model Pembelajaran Inkuiri Terbimbing. Scholaria: Jurnal Pendidikan Dan Kebudayaan, 10(2), 103-111. https://doi.org/10.24246/j.js.2020.v10.i2.p103-111

Kartika, N. M. D. (2017). Pengaruh Model Pembelajaran Inkuiri Terbimbing Berbantuan Peta Pikiran dan Motivasi Berprestasi terhadap Hasil Belajar IPA. Jurnal Mimbar PGSD Undiksha, 5(2). http://dx.doi.org/10.23887/jjpgsd.v5i2.10675.

Kemendikbud. (2016). Indonesian National Assesment Programme.

Krismayeni, P. M. L. (2016). Penerapan Model Pembelajaran Inkuiri Terbimbing untuk Meningkatkan Keaktifan dan Hasil Belajar Matematika. Jurnal Mimbar PGSD Undiksha, 4(2). http://dx.doi.org/10.23887/jjpgsd.v4i2.7696.

Lestari, G. A. M. (2017). Pengaruh Model Pembelajaran Inkuiri Terbimbing Berbantuan Mind Mapping terhadap Pemahaman Konsep IPA Siswa. Jurnal Mimbar PGSD Undiksha, 5(3). http://dx.doi.org/10.23887/jjpgsd.v5i3.12421.

Martini, S. (2018). Upaya Meningkatkan Hasil Belajar IPA Kelas V Menggunakan Metode Tutorial Teman Sebaya di SDN 022 Titian Tinggi Kecamatan Rengat Barat. Jurnal Mitra Pendidikan, 2(9). https://ejurnalmitrapendidikan.com/index.php/e-jmp/article/view/403.

Mastrianto, A. (2017). Efektivitas Penggunaan Model Pembelajaran Tutor Sebaya untuk Meningkatkan Minat Belajar Siswa. PESAGI Uurnal Pendidikan Dan Penelitian Sejarah), 5(8). http://jurnal.fkip.unila.ac.id/index.php/PES/article/view/14337.

Muhalizah. (2018). Pengaruh Metode Improve Terhadap Kreatifitas Siswa Kelas Vii A Mts Syekh Subakir Pada Materi Bangun Datar Muhalizah Institut Agama Islam Negeri ( IAIN ) Tulungagung PENDAHULUAN Matematika merupakan salah satu disiplin ilmu yang dipelajari dan diajarkan pa. MUST: Journal of Mathematics Education, Science and Technology, 3(1), 92-104. https://doi.org/https://doi.org/10.30651/must.v3i1.1613

Muliani, N. K. D. (2019). Pengaruh Model Pembelajaran Inkuiri Terbimbing Berbantuan Video terhadap Hasil Belajar IPA. Jurnal Ilmiah Sekolah Dasar, 3(1).

Musdiani. (2017). Penerapan Metode Tutor Sebaya untuk Meningkatkan Hasil Belajar Siswa Kelas IV SD 38 Banda Aceh pada Pokok Bahasan Operasi Hitung Bilangan Bulat. Tunas Bangsa Journal, 4(2). https://ejournal.bbg.ac.id/tunasbangsa.

OECD. (2016). Country Note - Results from PISA 2015: Indonesia. Oecd, 1-8.

OECD. (2018). What 15-year-old students in Indonesia know and can do. Programme for International Student Assessment (PISA) Result from PISA 2018, 1-10.

Padmayani, K. P. (2017). Pengaruh Model Problem Based Learning Berbantuan Tutor Sebaya terhadap Hasil Belajar Matematika Siswa Kelas V. Jurnal Mimbar PGSD Undiksha, 5(2). http://dx.doi.org/10.23887/jjpgsd.v5i2.10634.

Pratiwi, I. A., Ardianti, S. D., \& Kanzunnudin, M. (2018). Peningkatan Kemampuan Kerjasama Melalui Model Project Based Learning (Pjbl) Berbantuan Metode Edutainment Pada Mata Pelajaran Ilmu Pengetahuan SosiaL. Refleksi Edukatika: Jurnal Ilmiah Kependidikan, 8(2). https://doi.org/10.24176/re.v8i2.2357

Putra, I. K. D. A. S. (2017). Pengaruh Model Pembelajaran Inkuiri Terbimbing Berbantuan Peta Pikiran terhadap Hasil Belajar IPA Kelas V SD. Jurnal Mimbar PGSD Undiksha, 5(2). http://dx.doi.org/10.23887/jjpgsd.v5i2.10711.

Putra, L. V. (2018). Pembelajaran Matematika Model Tutor Sebaya dengan Strategi Heuristik VEE. 
JANACITTA Journal of Primary and Children's Education, 1(2). http://jurnal.unw.ac.id:1254/index.php/janacitta/article/view/80.

Sanjaya, W. (2010). Strategi Pembelajaran Berorientasi Standar Proses Pendidikan. In 1. Prenada Media Group.

Saraswati, N. L. (2013). Pengaruh Model Pembelajaran Inkuiri Terbimbing terhadap Hasil Belajar Matematika Siswa Kelas III SD Di Gugus I Kecamatan Buleleng. Jurnal Mimbar PGSD Undiksha, 1(1). http://dx.doi.org/10.23887/jjpgsd.v1i1.713.

Sarini, N. K. (2018). Hasil Belajar IPA Kelas IV SD di Gugus II Santalia melalui Tutor Sebaya. Jurnal Ilmiah Sekolah Dasar, 2(2). http://dx.doi.org/10.23887/jisd.v2i2.15486.

Sefalianti, B. (2014). Penerapan Pendekatan Inkuiri Terbimbing terhadap Kemampuan Komunikasi dan Disposisi Matematis Siswa. Jurnal Pendidikan Dan Keguruan, 1(2). https://www.neliti.com/publications/209697/penerapan-pendekatan-inkuiri-terbimbingterhadap-kemampuan-komunikasi-dan-dispos

Setiana, N. D. (2019). Pengaruh Metode Tutor Sebaya dalam Pembelajaran Kelas V SD N Mangunsari 06. Jurnal Review Pendidikan Dan Pengajaran, 2(1). https://journal.universitaspahlawan.ac.id/index.php/jrpp/article/view/268.

Setyosari, H. P. (2015). Metode Penelitian dan Pengembangan. Prenada Media Group.

Sobron, A. ., Bayu, Rani, \& Meidawati. (2019). Persepsi Siswa Dalam Studi Pengaruh Daring Learning Terhadap Minat Belajar IPA. SCAFFOLDING: Jurnal Pendidikan Islam Dan Multikulturalisme, 1(2), 30-38. https://doi.org/10.37680/scaffolding.v1i2.117.

Suwarti. (2019). Model Diskoveri Inkuiri Dan Penugasan Untuk Peningkatan Hasil Belajar Dan Keuletan Siswa Pada Pelajaran Kewirausahaan. Dewantara, VIII, 215-230. http://ejournal.iqrometro.co.id/index.php/pendidikan/article/download/113/95

Tetiwar, J. (2018). Penerapan Metode Peer tutoring untuk Meningkatkan Pemahaman Konsep Materi Perkalian Bersusun pada Siswa Kelas III SD. Scholaria: Jurnal Pendidikan Dan Kebudayaan, 8(3). https://ejournal.uksw.edu/scholaria/article/view/1818.

Ulfa, M. (2014). Pengaruh Penerapan Model Pembelajaran Kooperatif Teknik Tutor Sebaya terhadap Hasil Belajar TIK Ditinjau dari Motivasi Berprestasi pada Siswa Kelas VI SD Muhammadiyah 2 Denpasar. Jurnal Pendidikan Dasar Ganesha, 4. https://www.neliti.com/id/publications/123528/pengaruhpenerapan-model-pembelajaran-kooperatif-teknik-tutor-sebaya-terhadap-ha

Wati, A., Susilo, H., \& Sutopo. (2018). Pengaruh Pembelajaran Inkuiri Terbimbing Berbantuan Jurnal Belajar terhadap Penguasaan Konsep IPA Siswa. Jurnal Pendidikan, 3(1), 129-133. http://dx.doi.org/10.17977/jptpp.v3i1.10411.

Widani, N. K. T. (2019). Pengaruh Model Pembelajaran Inkuiri Terbimbing terhadap Hasil Belajar IPA dan Sikap Ilmiah pada Siswa Kelas V SD Gugus I Kecamatan Nusa Penida. Journal of Education Technology, 3(1). http://dx.doi.org/10.23887/jet.v3i1.17959. 